\title{
Uncoupling of the epidermal growth factor receptor from downstream signal transduction molecules guides the acquired resistance to gefitinib in prostate cancer cells
}

\author{
CLAUDIO FESTUCCIA ${ }^{1}$, GIOVANNI LUCA GRAVINA ${ }^{2}$, DANILO MILLIMAGGI ${ }^{1}$, PAOLA MUZI ${ }^{1}$, \\ SILVIA SPECA ${ }^{1}$, ENRICO RICEVUTO ${ }^{1}$, CARLO VICENTINI $^{2}$ and MAURO BOLOGNA ${ }^{1,3}$ \\ Departments of ${ }^{1}$ Experimental Medicine, ${ }^{2}$ Surgery, and ${ }^{3}$ Basic and Applied Biology, \\ University of L'Aquila, Coppito-2, 67100 L'Aquila, Italy
}

Received January 12, 2007; Accepted March 30, 2007

\begin{abstract}
The clinical efficacy of ErbB1 kinase inhibitors is limited by the development of acquired autoresistance. The activation of alternative signaling pathways can contribute to gefitinib resistance. In this study, we demonstrate that the continuous in vitro exposure of the phosphatase and tensin homologue (deleted from chromosome 10)-negative prostate cancer (PC) 3 cell line to gefitinib resulted in a sustained growth inhibition of $50 \%$ for about 2 months, but afterwards the surviving cells resumed their usual proliferation rate. During chronic treatment, gefitinib-treated cells developed drug resistance undergoing a G0/G1 cell cycle arrest, with a corresponding reduction in the $\mathrm{G} 2 / \mathrm{M}$ cells without evident cell apoptosis, and thus a tyrosine kinase inhibitor-resistant (TKI-R) PC3 cell subline was isolated. TKI-R cells show i) an increment in basal ERK activation, ii) an epidermal growth factor-mediated and gefitinib insensitive ERK phosporylation, iii) increased levels of Her $/ \mathrm{Neu}$, iv) a significant decrement in epidermal growth factor receptor (EGFR) expression, v) a very low sensitivity against EGFR TKIs and blocking antibodies, vi) a moderate increase in the sensitivity to growth inhibition by the Her2 inhibitor, AG825 or by $2 \mathrm{C} 4$, the humanized monoclonal antibody which blocks Her2 heterodymerization, vii) an increased expression of the neutrophine receptors, TrkA and TrkB, and viii) a significantly increased sensitivity to growth inhibition by the TrkA inhibitor, CEP701.
\end{abstract}

Correspondence to: Dr Claudio Festuccia, Department of Experimental Medicine, University of L'Aquila, Via Vetoio, Coppito-2, 67100 L'Aquila, Italy

E-mail: festucci@univaq.it

Abbreviations: RTK, receptor associated tyrosine kinase; EGFR, epidermal growth factor receptor; TKI, tyrosine kinase inhibitor; PI3K, phosphoinositide 3-kinase; PCa, prostate cancer; MAPK, mitogen-activated-protein kinase; PTEN, phosphatase and tensin homologue deleted from chromosome 10; TGF- $\alpha$, transforming growth factor $\alpha$; NSCLC, non small cell lung carcinoma

Key words: prostate cancer, epidermal growth factor receptor, gefitinib, drug resistance
Treatment with a mitogen-activated-protein kinase inhibitor abolished gefitinib resistance completely. Therefore, the ability of tumor cells to maintain high ERK activity under EGFR inhibition could represent a potential mechanism of the resistance to gefitinib.

\section{Introduction}

Despite initial positive response to androgen ablation therapy, virtually all patients with prostate cancer ( $\mathrm{PCa}$ ) develop hormone-refractory disease. The epidermal growth factor receptor (EGFR) or erbB1 is a proto-oncogene, which encodes a $170 \mathrm{kDa}$ protein (1) consisting of an extracellular ligandbinding domain, a transmembrane domain, an intracellular tyrosine kinase domain, and a carboxy-terminal regulatory domain containing sites of autophosphorylation. Upon the binding of its ligand, EGFR undergoes homo- and/or heterodymerization with other members of the same receptor family, including erbB2, erbB3, and erbB4, resulting in the addition of phosphate moieties to specific tyrosines, which can serve as docking sites for downstream effectors (2). In addition, a subset of human tumors is driven by the overexpression and overactivity of the EGFR family proteins (313). Also, many solid tumours also demonstrate an elevated expression of the corresponding EGFR ligands, EGF and the transforming growth factor- $\alpha$ (TGF- $\alpha)(14,15)$, suggesting that the receptor can be activated in an autocrine manner. In breast cancer, for example, EGFR overexpression has been associated with oestrogen receptor-negative disease and hence with poor prognosis (16-19), while in vitro studies have also implicated EGFR in the mediation of acquired resistance to anti-oestrogen therapy $(18,19)$. In $\mathrm{PCa} \sim 80 \%$ of cases display EGFR or Her2 gene overexpression (20-22) and it has been shown that ErbB1 expression is strongly associated with hormone-refractory status (23-28) and this suggests that drugs targeted toward ErbB signaling could be of therapeutic relevance in the management of advanced prostatic carcinoma. (22). Signal transduction through the ErbB receptor family involves the Raf-MEK-MAP kinase and the PI3-kinase/Akt signaling pathways. These pathways are often activated simultaneously with conflicting responses such as apoptosis, proliferation, growth arrest, differentiation, 
and senescence, depending on the cell type and the duration and strength of the stimulus.

Gefitinib is an oral nonpeptidic anilinoquinazolone compound that inhibits the TRK activity of the EGFR Erb$\mathrm{B} 1$ [with an $\mathrm{IC}_{50}$ of $0.02 \mu \mathrm{M}$, requiring a dose almost 200fold higher to inhibit HER2 Erb-B2, $3.7 \mu \mathrm{M}$; (29)]. Fabian et al (30) reported that gefitinib binds 16 kinases plus EGFR (with a $\mathrm{Kd}>1 \mu \mathrm{M}$ for all kinases, except GAK), the corresponding Kd for EGFR being 1000-fold higher, whereas for GAK (10-100 nM) the corresponding Kd for EGFR was about 10-fold higher. However, gefitinib can be used to specifically inhibit EGFR at doses lower than $10 \mu \mathrm{M}$. Gefitinib inhibits the growth of cell lines that express high levels of EGFR and induces the complete regression of well-established xenografts (31-35). In addition, we have demonstrated that gefitinib is able to reduce the invasiveness (36) and metastasis (37) of PCa cells. Gefitinib has been included in clinical trials in cancer patients, and antitumor activity has been demonstrated against several human cancers, such as recurrent or metastatic squamous head and neck cell carcinoma (Cohen et al personal communication), non small cell lung cancer (38-40) and prostate cancer (41). However, the clinical data have already demonstrated that not all patients respond to the inhibitor, indicating the existence of an intrinsic or de novo resistance to the drug $(38-40,42)$. However, although in vitro studies (43) have indicated a potential higher effectiveness of gefitinib in advanced $\mathrm{PCa}$ as a single therapeutic agent or in combination with chemotherapeutics, the drug has shown minimal single agent activity in the clinically advanced phases of the disease $(41,44)$. The acquisition of resistance to gefitinib has also been demonstrated in vitro, with the establishment of different gefitinib/erlotinib-resistant cell lines (45-57) due to EGFR secondary mutations in the tyrosine kinase inhibitor (TKI) domain in non small cell lung carcinoma (NSCLC) and oesophageal cancer $(52,53)$ as well as in the activation of alternative signaling pathways in breast cancer and $\mathrm{PCa}$ (52-54). In our study, we generated a model for the acquired resistance to gefitinib using an androgen-independent, EGFRpositive, (55) and phosphatase and tensin homologue deleted from chromosome 10 (PTEN)-negative PC3 cell line, with a slow sensitivity to gefitinib, in which an increased Her2- and TrkA-mediated mitogen-activated-protein kinase (MAPK) activation is involved.

\section{Materials and methods}

Reagents. All the materials for tissue culture were purchased from Hyclone (Cramlington, NE, USA). Plasticware was obtained from Nunc (Roskilde, Denmark). EGF was purchased from ImmunoTools (GmbH, Friesoythe, Germany). Antibodies were purchased from Santa Cruz (Santa Cruz, CA, USA) unless otherwise indicated. Antibodies against phosphorylated forms of EGFR, HER2 and ERK1/2 were obtained from Biosource International (Camarillo, CA, USA). Gefitinib was kindly provided from AstraZeneca Italia (Milan, Italy), PKI166 from Dr Peter Traxler, Novartis pharma, (Basel, Switzerland), erlotinib (Tarceva, OSI-774) from Dr Kenneth Iwata (OSI Pharmaceuticals Inc., Melville, NY, USA), and CEP701 from Dr Stephen Trusko, Cephalon Inc. (West Chester, PA, USA). The Her-2 specific inhibitor,
AG825, and the Trk-specific inhibitor, AG879, were purchased from Sigma-Aldrich (St. Louis, MA, USA). The humanized monoclonal antibody against Her2, pertuzumab (Omnitarg, $2 \mathrm{C} 4$ ), which is able to block its heterodymerization, kindly provided from Genentech Inc. (San Francisco, CA, USA), was also used.

Establishment of a PC3 cell subline resistant to the EGFR TKI gefitinib. The PC3 cell cultures were washed with Dulbecco's phosphate-buffered saline (PBS) and continuously exposed to gefitinib in routine culture medium which was replaced every 4 days. Initially, PC 3 cell numbers were dramatically reduced and during the following 2 months the surviving cells were passaged approximately every 10 days with a seeding ratio of 1:3. Cell proliferation slowly increased every 20 days with the seeding ratio increasing to 1:8 over the next 2 months. A stable growth rate was reached after a total of 6 months, with routine maintenance of the newly developed PC3/TKI-R cell subline involving cell culture passages every 7 days, with a seeding ratio of $1: 10$ of the confluent cell number.

Growth assays. Cells were seeded at a density of $2 \times 10^{4}$ cells per dish in $50 \mathrm{~mm}$ petri dishes. The cells were left to attach and grow in 5\% FCS DMEM for $24 \mathrm{~h}$. After this time, the cells were maintained in culture medium containing androgens or subjected to androgen depletion. The following day, three dishes were sacrificed for cell counting (time 0 ) in order to measure the baseline cell number, while the remaining dishes were medium changed. Morphological controls were performed every day with an inverted phase-contrast photomicroscope from Nikon Diaphot (Tokyo, Japan), before cell trypsinisation and counting. All other cells were treated with either $50 \mathrm{ng} / \mathrm{ml} \mathrm{EGF}$ or different doses of gefitinib. The cells trypsinised and resuspended in $20 \mathrm{ml}$ saline, were counted by a haemocytometer from LabRecyclers (Gaithersburg, MD, USA) every $24 \mathrm{~h}$ and 5 independent counts were performed for each dish. All experiments were conducted in triplicate. In order to calculate the inhibitory concentrations at $50 \% \mathrm{IC}_{50}$ of gefitinib, 2,500 cells were cultured in 96-well plates for 24-96 $\mathrm{h}$ in different culture conditions. After 48-96 h the cells were exposed for $4 \mathrm{~h}$ to thyazol blue MTS; Promega (Madison, WI, USA). The 96-well culture plates were then placed on a microplate shaker for $5 \mathrm{~min}$ and the absorbance of the converted dye was measured at the wavelength of $490 \mathrm{~nm}$ using a BioRad multiscan plate reader (BioRad, Richmond, CA, USA). Usually, 5 replicate wells were used for each group. Inhibition curves were drawn with values obtained by OD percentages vs the control for each concentration. $\mathrm{IC}_{50}$ was calculated by the GraFit method (Erithacus Software Ltd., Staines, UK) considering the slopes of inhibition curves obtained for each group of tests.

Preparation of cell lysates and Western blot analysis. Following the treatments, the cells were washed with cold PBS and immediately lysed with $1 \mathrm{ml}$ lysis buffer, $50 \mathrm{mM}$ HEPES pH 7.5, $150 \mathrm{mM} \mathrm{NaCl}, 10 \%$ glycerol, $1 \%$ Triton X100, 1 mM EDTA, 1 mM EGTA, 50 mM NaF, 1 mM sodium orthovanadate, $30 \mathrm{mM}$ p-nitrophenyl phosphate, $10 \mathrm{mM}$ sodium pyrophosphate, $1 \mathrm{mM}$ phenylmethylsulfonyl fluoride, 
Table I. Dose-dependent GO/G1 arrest and apoptosis in the PC3 cell line after 72-h treatment with gefitinib.

\begin{tabular}{lrrrrrr}
\hline & \multicolumn{6}{c}{ Gefitinib $(\mu \mathrm{M})$} \\
\cline { 2 - 7 } & Basal & 0.01 & 0.1 & 0.5 & 1 & 5 \\
\hline GO/G1 & 52.6 & 54.5 & 58.2 & 78.1 & 80.1 & 86.8 \\
G2/M & 17.6 & 18 & 17.4 & 11.4 & 11.7 & 13.2 \\
S & 29.9 & 27.5 & 25.4 & 10.5 & 8.2 & 0 \\
Apoptosis & $<3$ & 3.5 & 5.7 & 16.6 & 36.6 & 67.8 \\
\hline
\end{tabular}

$10 \mu \mathrm{g} / \mathrm{ml}$ aprotinin and $10 \mu \mathrm{g} / \mathrm{ml}$ leupeptin. The pellets were resuspended in a harvest buffer containing $10 \mathrm{mM}$ HEPES $\mathrm{pH} 7.9,50 \mathrm{mM} \mathrm{NaCl}, 0.5 \mathrm{M}$ sucrose, $0.1 \mathrm{mM}$ EDTA and $0.5 \%$ Triton $\mathrm{X}-100$ and incubated on ice for $5 \mathrm{~min}$. The cells were pelleted at $1,000 \mathrm{rpm}$ on a swinging table top Microfuge Beckman Instruments Inc. (Fullerton, CA, USA), washed and resuspended in $10 \mathrm{mM}$ HEPES pH 7.9 containing $10 \mathrm{mM}$ $\mathrm{KCl}, 0.1 \mathrm{mM}$ EDTA and $0.1 \mathrm{mM}$ EGTA. The pellets were vortexed for $15 \mathrm{~min}$ at $4^{\circ} \mathrm{C}$ and centrifuged at $14,000 \mathrm{rpm}$ for $10 \mathrm{~min}$ at $4^{\circ} \mathrm{C}$ before protein content was measured. The lysates were electrophoresed in 7\% SDS-PAGE, and the separated proteins were transferred to nitrocellulose and probed with the appropriate antibodies using the conditions recommended by the antibody suppliers.

Immunoperoxidase staining and immunofluorescent analysis. The cells were cultured in Lab-Tek Chamber slides from Nalgene Nunc International (Rochester, NY, USA) and treated as described in the 'growth assays' section. After 24$48 \mathrm{~h}$ of cell culture, the cells were washed in PBS and fixed either in 4\% PBS-paraformaldehyde for $5 \mathrm{~min}$ for the immunostaining of membrane associated antigens (EGFR/ HER2) or in cold 1:1 acetone:methanol mixture in ice for $2 \mathrm{~min}$ for the immunostaining of cellular or nuclear antigens (PSA and AR). Primary and secondary antibodies were used according to the manufacturer's protocols. The quantification of TrkA, B, C and p75 NGFR as well as that of EGFR/ HER2-positive cells was performed by flow cytometric analysis (FACScan; Becton-Dickinson, Mountain View, CA, USA). The cells were trypsinised, centrifuged and left at $37^{\circ} \mathrm{C}$ for $1 \mathrm{~h}$ in DMEM/10\% FCS in polypropylene tubes in order to reconstitute the cellular external membrane. The cells were washed in saline buffer and $1 \times 10^{6}$ cells were treated with about $10 \mu \mathrm{g} / \mathrm{ml}$ primary antibodies. After $1 \mathrm{~h}$ at $4^{\circ} \mathrm{C}$ the cells were washed twice in PBS and FITC-anti-rabbit and anti-mouse secondary antibodies (about $1 \mu \mathrm{g} / \mathrm{ml}$ ) were then added. After 30-min incubation at $4^{\circ} \mathrm{C}$, the cells were washed twice and resuspended in PBS at a density of $1 \times 10^{6}$ cells/ml before analysis using Cell Quest software (BectonDickinson).

Statistical analysis. Data are expressed as the means \pm SEM of at least three independent experiments. Statistical analysis was performed using an unpaired Student's t-test. The
Table II. Time-dependent GO/G1 arrest and apoptosis of the PC3 cell line treated with either $50 \mathrm{ng} / \mathrm{ml}$ EGF or $0.5 \mu \mathrm{M}$ gefitinib.

\begin{tabular}{lrrrr}
\hline & \multicolumn{4}{c}{ Treatment (h) } \\
\cline { 2 - 5 } Condition & 24 & 48 & 72 & 96 \\
\hline EGF & & & & \\
$\quad$ GO/G1 & 48 & 62.9 & 52.6 & 54.5 \\
G2/M & 21.6 & 19.7 & 17.6 & 11.7 \\
S & 31.4 & 33.4 & 29.9 & 33.8 \\
Apoptosis & $<3$ & $>3$ & $<3$ & $>3$ \\
Gefitinib & & & & \\
GO/G1 & 60.8 & 71.8 & 78.1 & 83 \\
G2/M & 32.1 & 25.2 & 11.4 & 8.5 \\
S & 7.1 & 3 & 10.6 & 8.5 \\
Apoptosis & 3.4 & 12.8 & 16.7 & 26.6 \\
\hline
\end{tabular}

EGF, epidermal growth factor.

comparison on the growth factor receptor expression was performed using Fisher's exact test. P-values $<0.05$ and $<0.01$ were considered statistically significant.

\section{Results}

Development and characterization of gefitinib-resistant PC3 cell line (PC3-TKI-R)

Role of phosphoinositide 3-kinase (PI3K) inhibition in the gefitinib sensitivity. In order to test the hypothesis that PI3K inhibition can contribute to gefitinib effectiveness, we performed gefitinib growth sensitivity assays in the presence of the PI3K inhibitor, LY294002. In this analysis, we found that the $\mathrm{IC}_{50}$ values calculated for the gefitinib treatment decreased in a statistical manner $(0.68 \pm 0.17$ and $0.11 \pm 0.06 \mu \mathrm{M}$, $\mathrm{P}<0.001)$ after treatment with non toxic LY294002 $(5 \mu \mathrm{M})$, reducing the Akt activity (data not shown). The decreased cell proliferation was associated to a dose- and time-dependent G1 arrest of the cell cycle and to an increased apoptosis rate as shown in Tables I and II.

Recovery time experiments. Next we cultured $2.5 \times 10^{3}$ PC3 cells per dish in 90-mm diameter petri dishes for 2 weeks changing the complete medium every 2 days and administering $0.5 \mu \mathrm{M}$ gefitinib every 24,48 and $72 \mathrm{~h}$. At these times we replaced the complete medium with a medium without the drug. We observed that although $0.5 \mu \mathrm{M}$ gefitinib interfered with the PC3 cell growth, suspension of the gefitinib treatment restored the PC3 cell growth with similar growth rates as shown in Table III.

Selection and characterization of gefitinib-resistant cells. In addition, we observed that PC3 cells grown in the presence of $0.5 \mu \mathrm{M}$ gefitinib were basally arrested in their growth for about 2 weeks. Next, PC3 cells grew in an evidently low gefitinib-dependent manner. Chronic treatment (1-6 months) with $1 \mu \mathrm{M}$ gefitinib induced gefitinib resistance. We observed 
Table III. Recovery time experiments.

\begin{tabular}{|c|c|c|c|c|c|}
\hline \multirow{2}{*}{$\begin{array}{l}\text { Recovery } \\
\text { conditions }\end{array}$} & \multicolumn{5}{|c|}{ Treatment (h) } \\
\hline & Basal & 24 & 48 & 96 & 120 \\
\hline \multicolumn{6}{|l|}{$24 \mathrm{~h}$} \\
\hline GO/G1 & 60.8 & 67.6 & 67.3 & 57 & 55.2 \\
\hline $\mathrm{G} 2 / \mathrm{M}$ & 32.1 & 28.7 & 22.5 & 24 & 19.7 \\
\hline $\mathrm{S}$ & 7.1 & 3.7 & 10.2 & 19 & 26.1 \\
\hline Apoptosis & 3.4 & 7.5 & 8.5 & $<3$ & $<3$ \\
\hline \multicolumn{6}{|l|}{$48 \mathrm{~h}$} \\
\hline GO/G1 & 71.8 & 75.2 & 72.2 & 67.5 & 65 \\
\hline G2/1V1 & 25.2 & 18.5 & 18.7 & 24 & 19.7 \\
\hline $\mathrm{S}$ & 3 & 6.3 & 9.1 & 9 & 16.3 \\
\hline Apoptosis & 12.8 & 12.5 & 17.5 & 9.5 & $<3$ \\
\hline \multicolumn{6}{|l|}{$72 \mathrm{~h}$} \\
\hline GO/G1 & 78.1 & 80 & 80.2 & 77.6 & 66.5 \\
\hline $\mathrm{G} 2 / \mathrm{M}$ & 11.4 & 7.4 & 8.2 & 17.4 & 32.2 \\
\hline $\mathrm{S}$ & 10.6 & 12.6 & 11.6 & 15 & 17.2 \\
\hline Apoptosis & 16.7 & 19 & 22.5 & 29.2 & 5.5 \\
\hline
\end{tabular}

PC 3 cells were cultured for 24,48 and $72 \mathrm{~h}$ in the presence of $0.5 \mathrm{mM}$ gefitinib, washed twice and incubated for $24,48,96$ and $120 \mathrm{~h}$ in complete medium containing $50 \mathrm{ng} / \mathrm{ml}$ epidermal growth factor.

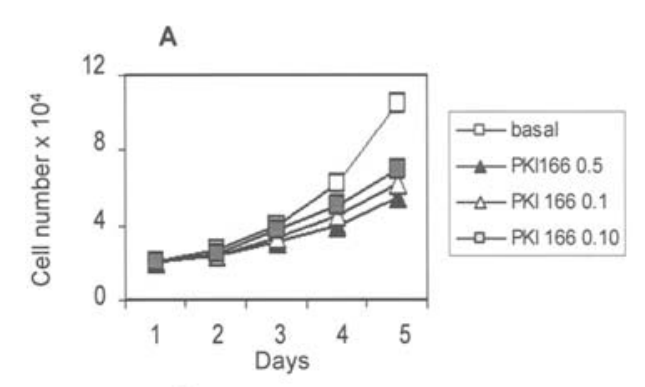

B

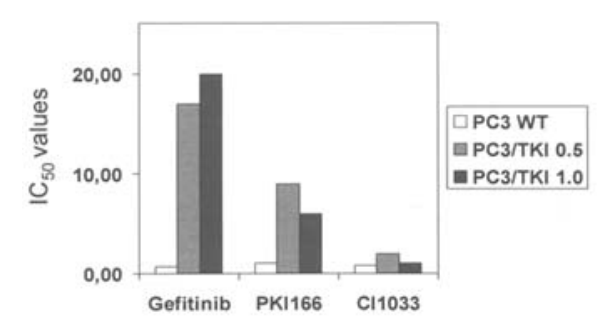

Figure 1. Effects of PKI166 and CI1033. (A) Growth curves in the presence of PKI166 in prostate cancer (PC)3 WT. (B) IC $_{50}$ values calculated for PKI166 and CI1033 in PC3 WT and TKI-R cells after 120 days of continous exposure to 0.5 and $1 \mu \mathrm{M}$ gefitinib.

that the $\mathrm{IC}_{50}$ values in PC3 cultured basally with $1 \mu \mathrm{M}$ gefitinib for $0,14,30$ and 160 days were statistically increased in time $(0.68 \pm 0.17,2.30 \pm 0.90,3.52 \pm 1.57,19.32 \pm 3.63 \mu \mathrm{M}$, respectively; ANOVA, $\mathrm{P}<0.001)$. In Fig. $1 \mathrm{~A}$ we show the effects of PKI166 on PC3 WT and in Fig. 1B the $\mathrm{IC}_{50}$ values
Table IV. Cell cycle analysis in the PC3 cells.

\begin{tabular}{|c|c|c|c|c|}
\hline Gefitinib & $\begin{array}{l}\text { Cell } \\
\text { cycle }\end{array}$ & PC3 & $\begin{array}{c}\text { PC3/ } \\
\text { TKI (0.5) }\end{array}$ & $\begin{array}{c}\text { PC3/ } \\
\text { TKI (1) }\end{array}$ \\
\hline \multirow[t]{4}{*}{ Basal } & GO/G1 & 52.6 & 52.9 & 63.2 \\
\hline & G2/M & 17.7 & 29.5 & 18.4 \\
\hline & $\mathrm{S}$ & 29.9 & 28.6 & 18.4 \\
\hline & Apoptosis & $<3$ & 4.2 & 8.8 \\
\hline \multirow[t]{4}{*}{$0.01 \mu \mathrm{M}$} & GO/G1 & 54.5 & 54.9 & 55.4 \\
\hline & G2/M & 18 & 30.5 & 28.4 \\
\hline & $\mathrm{S}$ & 27.5 & 25.6 & 16.4 \\
\hline & Apoptosis & 3.5 & 4.6 & 9 \\
\hline \multirow[t]{4}{*}{$0.1 \mu \mathrm{M}$} & $\mathrm{GO} / \mathrm{G} 1$ & 58.2 & 56 & 58.2 \\
\hline & G2iM & 17.4 & 23.5 & 20.4 \\
\hline & $\mathrm{S}$ & 25.4 & 20.5 & 21.4 \\
\hline & Apoptosis & 5.7 & 6 & 10 \\
\hline \multirow[t]{4}{*}{$0.5 \mu \mathrm{M}$} & GO/G1 & 78.1 & 57.3 & 58.2 \\
\hline & $\mathrm{G} 2 / \mathrm{M}$ & 11.4 & 28.5 & 21.1 \\
\hline & $\mathrm{S}$ & 10.5 & 15.2 & 20.7 \\
\hline & Apoptosis & 16.6 & 5.8 & 7.5 \\
\hline \multirow[t]{4}{*}{$1 \mu \mathrm{M}$} & GO/G1 & 80.1 & 62.2 & 60 \\
\hline & $\mathrm{G} 2 / \mathrm{M}$ & 11.7 & 22.1 & 25.4 \\
\hline & $\mathrm{S}$ & 8.2 & 15.2 & 14.6 \\
\hline & Apoptosis & 26.6 & 8.5 & 14.5 \\
\hline \multirow[t]{4}{*}{$5 \mu \mathrm{M}$} & GO/G1 & 86.8 & 73.1 & 71.8 \\
\hline & $\mathrm{G} 2 / \mathrm{M}$ & 13.2 & 16.4 & 15.2 \\
\hline & $\mathrm{S}$ & 0 & 10.5 & 13 \\
\hline & Apoptosis & 67.8 & 21.6 & 15.3 \\
\hline
\end{tabular}

PC 3 cells were cultured for 120 days in the presence of 0.5 and $1 \mu \mathrm{M}$ gefitinib, washed twice and incubated for $48 \mathrm{~h}$ in the presence of different doses of gefitinib.

obtained in PC3 WT and TKI-R after continous 120-day exposure to 0.5 and $1 \mu \mathrm{M}$ gefitinib. In Table IV we show the cell cycle analysis in the PC3 cells untreated and treated with 0.5 and $1 \mu \mathrm{M}$ gefitinib for 120 days. We also observed a cross-resistance with other TKI EGFR specific inhibitors including $\mathrm{AG} 1478\left(\mathrm{IC}_{50}\right.$ of $3 \mathrm{nM}$ for EGFR and $<100 \mu \mathrm{M}$ for Her2) and PKI166 or erlotinib (data not shown), whereas the pan EGFR inhibitor, CI1033, was effective in both the untreated and the gefitinib-resistant cells. Gefitinib chronic exposure was able to induce evident morphological cell changes in the PC3 cells as observed in Fig. 2, in which we show a progressive shift toward a fibroblast-like cell population. LY294002 was only able to partially sensitise the PC3-TKI-R cells, suggesting that PI3K is not involved in the gefitinib resistance phenomenon as shown in Fig. $3 \mathrm{~A}$ and $\mathrm{B}$ (3.5 vs $1.6 \mu \mathrm{M}$ gefitinib $\mathrm{IC}_{50}$ ). FACS analysis performed in PC3 WT and PC3/TKI-R treated with $0.5 \mu \mathrm{M}$ gefitinib showed a time-dependent increment in Her2/Neu expression, 

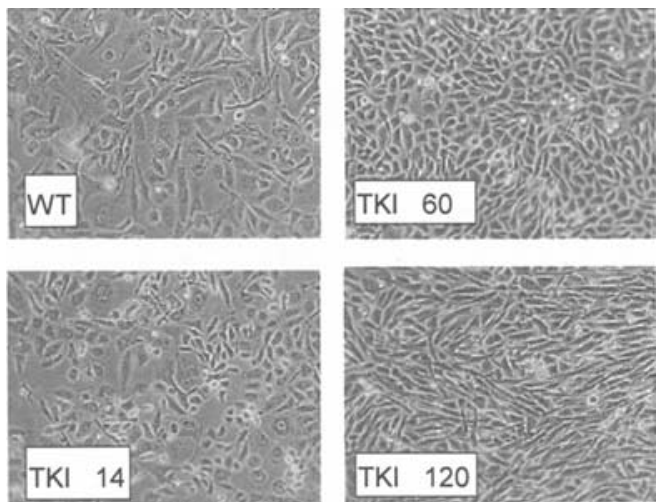

Figure 2. Phase contrast photomicrographs of prostate cancer (PC)3 cells during chronic treatment with gefitinib after 0,14,60 and 120 days of culture. (x200). PC3 cells grow as polygonal cells with very few intersecting cells. Some cells form small compact isles with elongated cells, especially in longterm treated cultures, with a final tendency to grow as fibroblastoid cells.

with a loss of the double Her2-positive cell populations having a fluorescent index of 1.5 and 3.5 (average 2.8), respectively, and with a larger (average 4,5 ) Her2/Neu-positive cell population. We also observed a parallel decrement in EGFR expression as is shown in Fig. 4. The FACS analysis (Fig. 4A) was confirmed by Western blotting (Fig. 4B). It has been shown that $\mathrm{p} 185 \mathrm{Her} 2 / \mathrm{Neu}$ overexpressing cells are more sensitive to AG825, a selective TKI preferentially inhibiting the HER-2/neu kinase, with respect to low expressing cells. Thus, we observed whether the effectiveness of this drug was different in parental PC3 and TKI-R cells. Using the humanized anti-Her2 antibody (2C4, pertuzumab) we observed similar results (data not shown). As expected, the increased expression of Her2 in the PC3-TKI-R cells was associated to an increased antiproliferative effect vs AG825 $\left(\mathrm{IC}_{50} 0.35 \mu \mathrm{M}\right.$ for Her2 and $19 \mu \mathrm{M}$ for EGFR) as indicated in Fig. $4 \mathrm{C}$ when compared to the parental cells. An increment
A
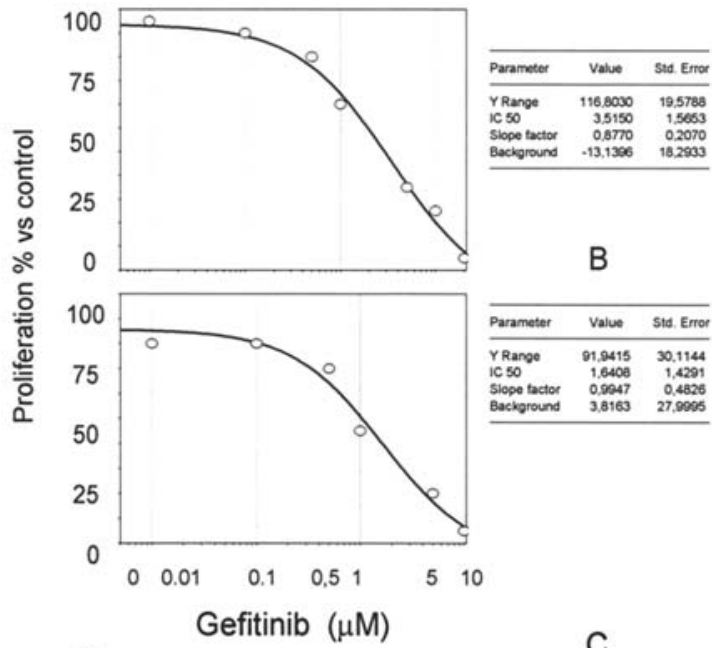

B

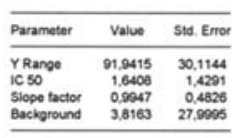

C

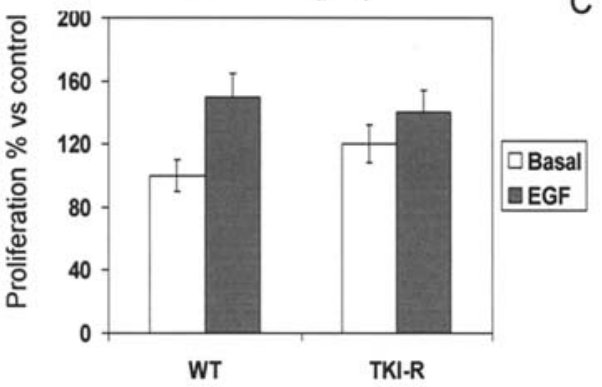

Figure 3. Dose-response of the anti-proliferative effects of gefitinib. (A) TKI-R prostate cancer (PC)3 cells. Cells $\left(1 \times 10^{4}\right)$ were cultured in 24-well plates, and after adhesion the cells were grown under different culture conditions in triplicate. After $48 \mathrm{~h}$ cells were fixed with methanol and stained with $10 \%$ crystal violet. Single plates were photographed with a digital camera. Single wells were treated with acid methanol in order to extract the crystal violet. In order to calculate the $\mathrm{IC}_{50}$ values, crystal violet $(200 \mu 1)$ solution was transferred to flat-bottomed 96 -well culture plates and analysed at $595 \mathrm{~nm}$. (B) $\mathrm{IC}_{50}$ value calculated in PC3 cells for gefitinib in the presence of $5 \mu \mathrm{M}$ LY294002. (C) This panel shows the comparison of epidermal growth factor effects between WT and TKI-R cells.
A

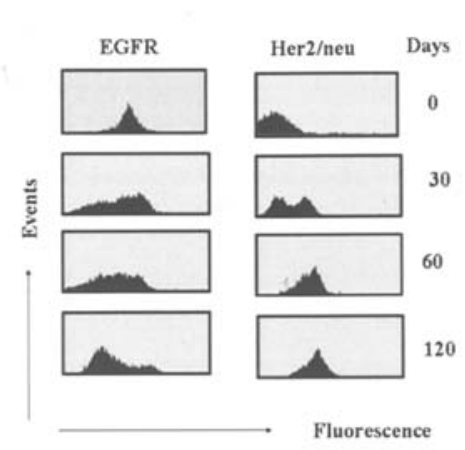

C

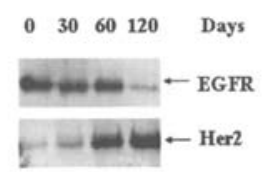

B

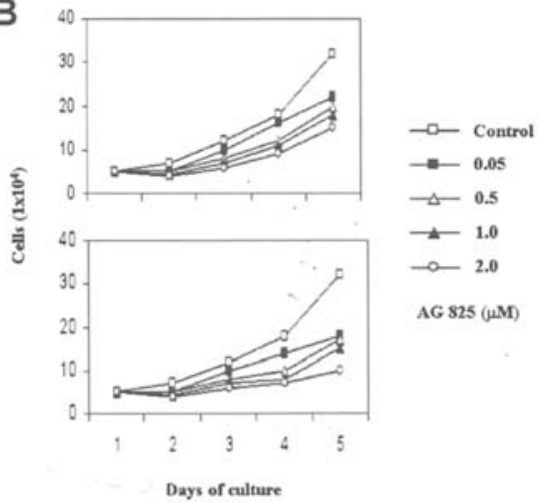

E

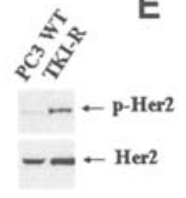

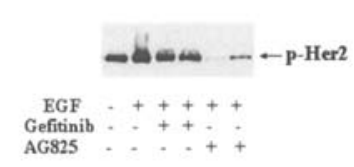

Figure 4. (A) EGFR and Her2 expression in WT and TKI-R prostate cancer (PC) 3 cells during chronic gefitinib treatment at 0, 30, 60, 120 days of culture by FACS analyses. (B) Dose-dependent antiproliferative effects of the Her2-specific TKI, AG825 $(\mu \mathrm{M})$, in PC3 WT and TKI-R cells in a growth curve experiment. (C) Western blot evidences. (D) Expression of basal p-Her2 in parental and TKI cells. (E) Epidermal growth factor (EGF)-mediated p-Her2 activation (30 min of $50 \mathrm{ng} / \mathrm{ml}$ EGF treatment) in TKI-R cells. Western blot evidences were performed using $40 \mu \mathrm{g} / \mathrm{lane}$ of total cell lysate protein. 

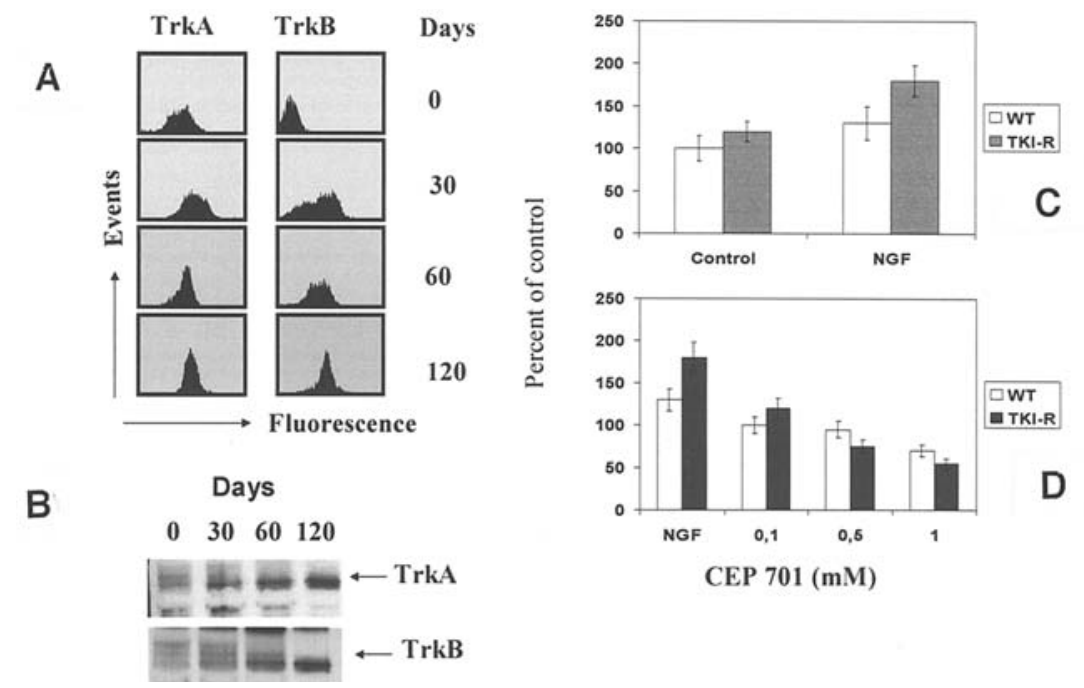

Figure 5. TrkA and TrkB expression in WT and TKI-R prostate cancer (PC) 3 cells. (A) Cytofluorimetric evidence: Comparison between PC 3 during chronic gefitinib treatment at $0,30,60,120$ days of culture. (B) Western blot evidences at the same times: We used $40 \mu \mathrm{g} / \mathrm{lane}$ of total cell lysate protein. (C) NGF $(10 \mathrm{ng} / \mathrm{ml})$ induces growth both in parental and TKI-R cells. This effect was higher in TKI-R with respect to the parental cells. (D) A TrkA inhibitor such as CEP701, is able to block NGF-induced TKI-R cell proliferation in a dose-dependent manner.

A

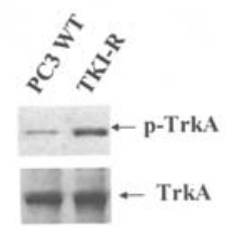

B

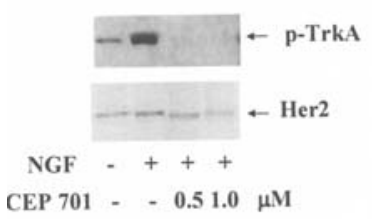

C

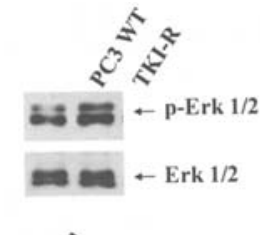

D

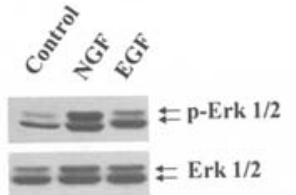

$\mathbf{E}$ NGF $10 \mathrm{ng} / \mathrm{ml}$

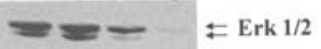

CEP 701

Figure 6. Expression of basal p-TrkA in parental and TKI-R prostate cancer(3) cells (A), and NGF-mediated p-TrkA activation with $30 \mathrm{~min}$ of $10 \mathrm{ng} / \mathrm{ml} \mathrm{NGF}$ treatment in TKI-R cells (B), by Western blotting. Expression of p-Erk in parental and TKI-R cells (C). Epidermal growth factor $(50 \mathrm{ng} / \mathrm{ml})$ and NGF (10 ng/ml) were able to induce p-Erk in TKI-R cells (D) as well as in parental cells (data not shown). CEP701 blocks Erk activation (E) in NGF-treated cells and AG825 blocks EGF-mediated Erk activation (data not shown). For Western blot analysis we used $40 \mu \mathrm{g} /$ lane of total cell lysate protein.

(two-fold) in Her2 phosphorylation was observed in the untreated TKI-R cells (Fig. 4D). In addition, $50 \mathrm{ng} / \mathrm{ml}$ EGF was able to induce p-Her2 levels after $15 \mathrm{~min}$ of treatment and this effect was blocked by $0.5 \mu \mathrm{M}$ AG825 but not by $0.5 \mu \mathrm{M}$ gefitinib (Fig. 4E). Also, it has been shown that treatment of cells with EGF (ErbB1-specific) or heregulin (ErbB4-specific) resulted in a hierarchic transactivation of ErbB2 and ErbB3 dependent on GF binding specificity. It is possible that in TKI-R cells the major receptors for EGF/TGF $\alpha$ are the homo- and heterodimers of Her2 which are insensitive to gefitinib. An increment in the neurotrophine receptors, NTRK1 (Trk A) and NTRK2 (Trk B), was also observed (Fig. 5A and B) whithout the modulation of NTRK3 (Trk C) and p75 NTR expression (data not shown). TrkA is a highly

specific NGF receptor. P75NTR represents a low affinity NGF receptor and is expressed at very low (often undetectable) levels in PC3 cells and in undifferentiated PCa cells. We observed that TKI-R cells were more sensitive to $10 \mathrm{ng} / \mathrm{ml}$ NGF treatment with respect to the parental cells as observed in Fig. 5C. In addition, the effects with both the commercial $\mathrm{AG} 879\left(\mathrm{IC}_{50} 10 \mu \mathrm{M}\right)$ and $\mathrm{CEP} 701\left(\mathrm{IC}_{50} 0.5 \mu \mathrm{M}\right)$ were higher in PC3-TKI-R when compared to the parental cells (Fig. 5D). The levels of the phosphorylated form of TrkA were higher in TKI-R vs WT PC3 cells as shown in Fig. 6A and CEP701 was able to abrogate this activation status (Fig. 6B). In addition, we observed that NGF was able to activate Her2/ Neu and its phosphorylation was reduced by CEP701 (Fig. 6B).

EGF and NGF were able to induce Erk activation both in PC3 WT and in TKI-R cells. In Fig. 6D we show the Erk activation in TKI-R cells. As opposed to the parental cells, gefitinib treatment was not able to reduce Erk activation (data not shown), whereas CEP701 (Fig. 6E) or AG825 (data not shown) were able to significantly reduce Erk activity, supporting the idea that the basal and GF-dependent increment in the MAPK activation was associated with gefitinib resistance. In addition, NGF was able to induce Her2 phosphorylation (data not shown, manuscript in preparation) in a ligand-independent manner suggesting that the cooperation between TrkA and Her2 is important in the progression of $\mathrm{PCa}$ and that a dual inhibition could represent an important mechanism for reducing epigenetic changes accompanying several phases of drug resistance.

\section{Discussion}

Clinical data have already demonstrated that the prevention of EGFR-mediated signal transduction by the small molecule inhibitor, gefitinib, provides a promising new treatment option for a variety of cancer types. The data documented the existence of an intrinsic or de novo resistance to the drug. To date, resistance to gefitinib has been associated to PTEN loss $(46,55,56)$, RAS mutations $(45,57)$ or the upregulation of the 
insulin-like growth factor 1 receptor (IGF-1R) (46) or EGFR mutations $(47,48)$. In our study, the continuous exposure of PC3 cells to gefitinib resulted in a sustained growth inhibition (50\%) for about 2 months before the surviving cells resumed proliferation. A stable gefitinib-resistant subline (PC3/TKI-R) was established after four more months. During drug desensitization experiments we observed a time-dependent increment of gefitinib $\mathrm{IC}_{50}$ (from 0.68 to $>15 \mu \mathrm{M}$ ). Moreover, gefitinib was still able to induce the cells which had already been treated for 8 weeks, developing resistance undergoing a G0/G1 cell cycle arrest with a corresponding reduction in the G2/M cells without evident cell apoptosis. PC3 cells showed a substantial growth inhibition when initially challenged with gefitinib. The surviving population, however, eventually resumed proliferation even though a successful blockade of EGFR signal transduction was evident in these cells. After the onset of gefitinib resistance, we observed an increased MEK-MAPK activity. Inhibition with PD 98059 was able to reduce cell proliferation and induce cell apoptosis in TKI-R cells. Chronic treatment with gefitinib was also able to induce strong changes in cell shape, with an increment in the fibroblast-like cell proportion, and an increased basal p-Her2 expression. No specific Her2 ligands are evident if EGF, TGF- $\alpha$ and HB-EGF bind to the heterodimers of EGFR/Her2 or if heregulins bind to the heterodimers of Her2 containing erbB3 (Her3) and erbB4 (Her4). PC3 cells are negative for the Her4 protein but express erbB3. Our observations are in agreement with those of Jain et al (54), who used an in vivo system to generate TKI-R cells from the CWR22R PCa xenograft in which the serial passages into gefitinib-treated nude mice produced a gefitinib-resistant tumor within three generations. When treated with $2 \mathrm{C} 4$ pertuzumab, a humanized monoclonal antibody targeted to an epitope of the Her-2 extracellular domain (that inhibits the heterodymerization of Her-2 with EGFR, Her-3 and Her-4), TKI-R CWR22R tumor growth was inhibited by $60 \%$. The TKI-R PC3 PCa cells showed a substantial growth promotion following the challenge with NGF and were clearly more responsive to this ligand as compared to the parental cells. In addition, a significant increase in basal TrkA phosphorylation was demonstrated in the gefitinib-resistant population compared with the parental cells. Furthermore, the enhanced role postulated for TrkA (59-62) in mediating the growth of TKI-R PCa was reinforced by dose-response studies, in which significant differences in the sensitivity to TrkA TKI CEP701 $(61,62)$ were shown in the TKI-R cell line compared with the parental line. Clearly, the prostate gefitinib-resistant phenotype compensated for the EGFR blockade via Her2 and/or TrkA signalling. The PC3/TKI-R prostate cells increased TrkA expression and NGF sensitivity to TrkA inhibition, whereas the parental PC3 cells were only partially affected by the TrkA inhibitor. On the acquisition of resistance to the EGFR inhibitor, however, PC3 cells acquired $\sim 50 \%$ growth inhibition in response to the inhibition of TrkA. This implies that there is no modulation or interplay between these pathways in the prostate cells but merely a switch in pathways with the intervention described. In addition, it has been shown that in breast cancer, NGF collaborates with Her2 in the activation of an overproliferative phenotype (63) and in pheocromocitoma cells, PC112 NGF downregulates Her2 expression (64).
In addition, Her2 has been shown to heterodymerize with IGF-1R (65) and to contribute to gefitinib resistance. Another possible cause for the gefitinib resistance could be the acquisition of new or secondary EGFR gene mutations affecting the TK domain. It has been shown $(50,51)$ that gefitinib and erlotinib are able to induce resistance by secondary mutations of the EGFR TK domain $(45,52)$. However, although these mutations have been demonstrated to confer drug resistance, we did not consider these EGFR mutations as being responsible for the gefitinib resistance in PCa cells through several functional evidences: i) EGFR was able to be activated by its ligands such as EGF, both in untreated or gefitinib-resistant cells, and ii) 0.5-10 $\mu \mathrm{M}$ gefitinib was able to block both basal and EGF-mediated p-EGFR expression in intact cells. Therefore, this simple functional approach demonstrates that mutations such as T790M, which affect tyrosine activity, if they are present, do not involve threonine 790. In conclusion, compared with the parental cells, TKI-R PC3 PCa cells show i) an increment in the basal ERK activation levels, ii) an EGF-mediated and gefitinib insensitive ERK phosporylation, iii) increased levels of Her2/Neu, iv) a significant decrement in EGFR expression and activity, v) an increased sensitivity to growth inhibition by AG825, an Her2 inhibitor, vi) an increased expression of the neutrophine receptors, TrkA and TrkB, without modulation in Trk C and p75 NTR, and vii) an increased sensitivity to growth inhibition by CEP701. In addition, MAPK inhibition abolished gefitinib resistance completely, supporting the idea that MAPK activation was associated with gefitinib efficacy and resistance in the PTEN-negative PC3 cells. Such data support the importance of the utilisation of chronic exposure models in order to delineate mechanisms of acquired drug resistance as they may reflect the clinical scenario more closely than acute drug challenges. These data have important predictive and therapeutic clinical implications: These results can help to explain the molecular responses in gefitinibresistant prostate tumors and to improve the chemotherapeutic strategies for their clinical treatment. Moreover, the existence of multiple proliferation signaling pathways in cancer cells could favor the choice of multidrug chemotherapy strategies vs monochemotherapy, with the perspective of higher efficacy paralleled by lower side-effects with multiple regimens using lower doses of each drug as compared to monotherapies.

\section{References}

1. Gullick WJ: The type 1 growth factor receptors and their ligands considered as a complex system. Endocr Relat Cancer 8: 75-82, 2001.

2. Moghal N and Sternberg PW: Multiple positive and negative regulators of signaling by the EGF-receptor. Curr Opin Cell Biol 11: 190-196, 1999 .

3. Hudziak RM, Schlessinger J and Ullrich A: Increased expression of the putative growth factor receptor p185HER2 causes transformation and tumorigenesis of NIH 3 T3 cells. Proc Natl Acad Sci USA 84: 7159-7163, 1987.

4. Cerny T, Barnes DM, Hasleton P, et al: Expression of epidermal growth factor receptor (EGF-R) in human lung tumours. Br J Cancer 54: 265-269, 1986.

5. Bradley SJ, Garfinkle E, Walker R, et al: Increased expression of the epidermal growth factor receptor on human colon carcinoma cells. Arch Surg 121: 1242-1247, 1986.

6. Weichselbaum RR, Dunphy EJ, Beckett MA, et al: Epidermal growth factor receptor gene amplification and expression in head and neck cancer cell lines. Head Neck 11: 437-442, 1989. 
7. Haura EB, Zheng Z, Song L, et al: Activated epidermal growth factor receptor-stat-3 signaling promotes tumor survival in vivo in non-small cell lung cancer. Clin Cancer Res 11: 8288-8294, 2005.

8. Murakawa T, Tsuda H, Tanimoto T, Tanabe T, et al: Expression of KIT, EGFR, HER-2 and tyrosine phosphorylation in undifferentiated thyroid carcinoma: Implication for a new therapeutic approach. Pathol Int 55: 757-765, 2005.

9. Reis-Filho JS, Milanezi F, Carvalho S, et al: Metaplastic breast carcinomas exhibit EGFR, but not HER2, gene amplification and overexpression: immunohistochemical and chromogenic in situ hybridization analysis. Breast Cancer Res 7: R1028-R1035, 2005.

10. Esteva FJ, Hortobagyi GN, Sahin AA, et al: Expression of erbB/HER receptors, heregulin and P38 in primary breast cancer using quantitative immunohistochemistry. Pathol Oncol Res 7: 171-177, 2001

11. Burgess AW, Cho HS, Eigenbrot C, et al: An open-and-shut case? Recent insights into the activation of EGF/ErbB receptors. Mol Cell 12: 541-552, 2003.

12. Vizoso F, Villar C, Rodriguez JC, et al: C-erbB-2 oncoprotein content in colorectal cancer and in surrounding mucosa: relationship with clinicopathologic parameters and prognostic significance. Int J Surg Investig 1: 483-493, 2000.

13. Tsutsui S, Kataoka A, Ohno S, et al: Prognostic and predictive value of epidermal growth factor receptor in recurrent breast cancer. Clin Cancer Res 8: 3454-3460, 2002.

14. Alper O, Bergmann-Leitner ES, et al: Epidermal growth factor receptor signalling and the invasive phenotype of ovarian carcinoma cells. J Natl Cancer Inst 93: 1375-1384, 2001.

15. Scher HI, Sarkis A, Reuter V, et al: Changing pattern of expression of the epidermal growth factor receptor and transforming growth factor alpha in the progression of prostatic neoplasms. Clin Cancer Res 1: 545-550, 1995.

16. Di Marco E, Pierce JH, Fleming TP, et al: Autocrine interaction between TGF alpha and EGF-receptor: quantitative requirements for induction of the malignant phenotype. Oncogene 4: 831-838, 1989

17. Knowlden J, Hutcheson IR, Jones HE, et al: Elevated levels of EGFR/c-erbB2 heterodimers mediate an autocrine growth regulatory pathway in tamoxifen resistant MCF-7 cells. Endocrinology 144: 1032-1044, 2003.

18. Van Agthoven TT, van Agthoven TL, Portengen $\mathrm{H}$, et al: Ectopic expression of epidermal growth factor receptors induces hormone independence in ZR-75-71 human breast cancer cells. Cancer Res 52: 5082-5088, 1992.

19. McClelland RA, Barrow D, Madsen T, et al: Enhanced epidermal growth factor receptor signalling in MCF7 breast cancer cells following long-term culture in the presence of the pure antioestrogen FASLODEX ${ }^{\mathrm{TM}}$. Endocrinology 142: 2776-2788, 2001.

20. Suo Z, Risberg B, Kalsson MG, et al: EGFR family expression in breast carcinomas. c-erbB-2 and c-erbB-4 receptors have different effects on survival. J Pathol 196: 17-25, 2002.

21. El Sheikh SS, Domin J, Abel P, et al: Phosphorylation of both EGFR and ErbB2 is a reliable predictor of prostate cancer cell proliferation in response to EGF. Neoplasia 6: 846-853, 2004.

22. Edwards J, Traynor P, Munro AF, et al: The role of HER1HER4 and EGFRvIII in hormone-refractory prostate cancer. Clin Cancer Res 12: 123-130, 2006.

23. Shah RB, Ghosh D and Elder JT: Epidermal growth factor receptor ErbB1 expression in prostate cancer progression: Correlation with androgen independence. Prostate 66: 1-8, 2006.

24. Di Loreto G, Tortora G, D'Armiento FP, et al: Expression of epidermal growth factor receptor correlates with disease relapse and progression to androgen-independence in human prostate cancer. Clin Cancer Res 8: 3438-3444, 2002.

25. Gravina GL, Festuccia C, Angelucci A, et al: Long-term presence of androgens and anti-androgens modulate EGFreceptor expression and MAP-kinase phosphorylation in androgen receptor-prostate positive cancer cells. Int J Oncol 25: 97-104, 2004

26. Skacel M, Ormsby AH, Pettay JD, et al: Aneusomy of chromosomes 7, 8, and 17 and amplification of HER-2/neu and epidermal growth factor receptor in Gleason score 7 prostate carcinoma: a differential fluorescent in situ hybridization study of Gleason pattern 3 and 4 using tissue microarray. Hum Pathol 32: 1392-1397, 2001

27. Connolly JM and Rose DP: Autocrine regulation of DU145 human prostate cancer cell growth by epidermal growth factorrelated polypeptides. Prostate 19: 173-180, 1991.
28. Gioeli D, Mandell JW, Petroni GR, et al: Activation of mitogenactivated protein kinase associated with prostate cancer progression. Cancer Res 59: 279-284, 1999.

29. Arteaga CL and Johnson DH: Tyrosine kinase inhibitorsZD1839 (Iressa). Curr Opin Oncol 13: 491-498, 2001.

30. Fabian MA, Biggs WH III, Treiber DK, et al: A small molecule-kinase interaction map for clinical kinase inhibitors. Nat Biotechnol 23: 329-336, 2005.

31. Ciardiello F, Caputo R, Bianco R, et al: Antitumour effect and potentiation of cytotoxic drugs activity in human cancer cells by ZD1839 (Iressa), an epidermal growth factor receptor-selective tyrosine kinase inhibitor. Clin Cancer Res 6: 2053-2063, 2000 .

32. Mellinghoff IK, Tran C and Sawyers CL: Growth inhibitory effects of the dual ErbB1/ErbB2 tyrosine kinase inhibitor PKI166 on human prostate cancer xenografts. Cancer Res 62 5254-5259, 2002.

33. Sirotnak FM, She Y, Lee F, et al: Studies with CWR22 xenografts in nude mice suggest that ZD1839 may have a role in the treatment of both androgen-dependent and androgen-independent human prostate cancer. Clin Cancer Res 8: 3870-3876, 2002.

34. Sirotnak FM, Zakowski MF, Miller VA, et al: Efficacy of cytotoxic agents against human tumour xenographs is markedly enhanced by co-administration of ZD1839 (Iressa), an inhibitor of EGF receptor tyrosine kinase. Clin Cancer Res 6: 4885-4892, 2000.

35. Asakuma J, Sumitomo M, Asano T, et al: Modulation of tumor growth and tumor induced angiogenesis after epidermal growth factor receptor inhibition by ZD1839 in renal cell carcinoma. J Urol 171: 897-902, 2004

36. Festuccia C, Angelucci A, Gravina GL, et al: Epithelial growth factor modulates prostate cancer cell invasiveness regulating urokinase type plasminogen activator activity: EGFR inhibition may prevent tumor cell dissemination. Thromb Haemost 93 : 964-975, 2005.

37. Angelucci A, Gravina GL, Rucci N, et al: Suppression of EGF$\mathrm{R}$ signalling reduces the incidence of prostate cancer metastasis in nude mice. Endocr Relat Cancer 13: 197-210, 2006.

38. Herbst RS, Maddox AM, Rothenberg ML, et al: Selective oral epidermal growth factor receptor tyrosine kinase inhibitor ZD1839 is generally well tolerated and has activity in nonsmall-cell lung cancer and other solid tumors: Results of a phase I trial. J Clin Oncol 20: 3815-3825, 2002.

39. Kris MG, Natale RB, Herbst RS, et al: Efficacy of gefitinib, an inhibitor of the epidermal growth factor receptor tyrosine kinase, in symptomatic patients with non-small cell lung cancer: A randomized trial. JAMA 290: 2149-2158, 2003.

40. Canil CM, Moore MJ, Winquist E, et al: Randomized phase II study of two doses of gefitinib in hormone-refractory prostate cancer: a trial of the National Cancer Institute of CanadaClinical Trials Group. J Clin Oncol 23: 455-460, 2005.

41. LoRusso PM, Herbst RS, Rischin D, et al: Improvements in quality of life and disease-related symptoms in phase I trials of the selective oral epidermal growth factor receptor tyrosine kinase inhibitor ZD1839 in non-small cell lung cancer and other solid tumors. Clin Cancer Res 9: 2040-2048, 2003.

42. Vicentini C, Festuccia C, Gravina GL, et al: Prostate cancer cell proliferation is strongly reduced by the epidermal growth factor receptor tyrosine kinase inhibitor ZD1839 in vitro on human cell lines and primary cultures. J Cancer Res Clin Oncol 129: $165-174,2003$.

43. Wilding G, Soulie P, Trump D, Das-Gupta A and Small E: Results from a pilot Phase I trial of gefitinib combined with docetaxel and estramustine in patients with hormone-refractory prostate cancer. Cancer 106: 1917-1924, 2006.

44. Koizumi F, Shimoyama T, Taguchi F, et al: Establishment of a human non-small cell lung cancer cell line resistant to gefitinib. Int J Cancer 116: 36-44, 2005.

45. Pao W, Wang TY, Riely GJ, et al: HEKRAS mutations and primary resistance of lung adenocarcinomas to gefitinib or erlotinib. PLoS Med 2: e73, 2005.

46. She QB, Solit D, Basso A, et al: Resistance to gefitinib in PTEN-null HER-overexpressing tumor cells can be overcome through restoration of PTEN function or pharmacologic modulation of constitutive phosphatidylinositol 3'-kinase/Akt pathway signaling. Clin Cancer Res 9: 4340-4346, 2003.

47. Jones HE, Goddard L, Gee JM, et al: RIInsulin-like growth factor-I receptor signalling and acquired resistance to gefitinib ZD1839; (Iressa) in human breast and prostate cancer cells. Endocr Relat Cancer 11: 793-814, 2004 
48. Jones HE, Gee JM, Barrow D, Tonge D, Holloway B and Nicholson RI: Inhibition of insulin receptor isoform-A signalling restores sensitivity to gefitinib in previously de novo resistant colon cancer cells. Int J Cancer 95: 172-180, 2006.

49. Erjala K, Sundvall M, Junttila TT, et al: Signaling via ErbB2 and ErbB3 associates with resistance and epidermal growth factor receptor (EGFR) amplification with sensitivity to EGFR inhibitor gefitinib in head and neck squamous cell carcinoma cells. Clin Cancer Res 12: 4103-4111, 2006.

50. Guo M, Liu S, Herman JG, Zhuang H and Lu F: Gefitinibsensitizing mutation in esophageal carcinoma cell line Kyse450. Cancer Biol Ther 5: 152-155, 2006.

51. Greulich H, Chen TH, Feng W, et al: Oncogenic transformation by inhibitor-sensitive and -resistant EGFR mutants. PLoS Med 2: e313, 2005

52. Tracy S, Mukohara T, Hansen M, Meyerson M, Johnson BE and Janne PA: Gefitinib induces apoptosis in the EGFRL858R non-small-cell lung cancer cell line H3255. Cancer Res 64: 7241-7244, 2004.

53. Ji H, Zhao X, Yuza Y, Shimamura T, et al: Epidermal growth factor receptor variant III mutations in lung tumorigenesis and sensitivity to tyrosine kinase inhibitors. Proc Natl Acad Sci USA 103: 7817-7822, 2006.

54. Jain A, Tindell CA, Laux I, et al: Epithelial membrane protein-1 is a biomarker of gefitinib resistance. Proc Natl Acad Sci USA 102: 11858-11863, 2005.

55. Festuccia C, Gravina GL, Biordi L, et al: Molecular aspects of Gefitinib 'Iressa' antiproliferative and pro-apoptotic effects in PTEN positive and PTEN negative prostate cancer cell lines. Endocr Relat Cancer 12: 983-998, 2005.

56. Kokubo Y, Gemma A, Noro R, et al: Reduction of PTEN protein and loss of epidermal growth factor receptor gene mutation in lung cancer with natural resistance to gefitinib (IRESSA). Br J Cancer 92: 1711-1792, 2005.
57. Suzuki T, Nakagawa T, Endo H, et al: The sensitivity of lung cancer cell lines to the EGFR-selective tyrosine kinase inhibitor ZD1839 'Iressa' is not related to the expression of EGFR or HER-2 or to K-ras gene status. Lung Cancer 42: 35-41, 2003.

58. Satoh F, Mimata H, Nomura T, et al: Autocrine expression of neurotrophins and their receptors in prostate cancer. Int $\mathrm{J}$ Urol 8: S28-S34, 2001.

59. Miknyoczki SJ, Wan W, Chang H, Dobrzanski P, Ruggeri BA, Dionne CA and Buchkovich K: The neurotrophin-trk receptor axes are critical for the growth and progression of human prostatic carcinoma and pancreatic ductal adenocarcinoma xenografts in nude mice. Clin Cancer Res 8: 1924-1931, 2002.

60. Weeraratna AT, Arnold JT, George DJ, DeMarzo A and Isaacs JT: Rational basis for trk inhibition therapy for prostate cancer. Prostate 45: 140-148, 2000

61. Dionne CA, Camoratto AM, Jani JP, et al: Cell cycle-independent death of prostate adenocarcinoma is induced by the trk tyrosine kinase inhibitor CEP-751 (KT6587). Clin Cancer Res 4: 1887-1898, 1998.

62. Tagliabue E, Castiglioni F, Ghirelli C, Modugno M, Asnaghi L, Somenzi G, Melani C and Menard S: Nerve growth factor cooperates with p185(HER2) in activating growth of human breast carcinoma cells. J Biol Chem 275: 5388-5394, 2000.

63. Oshima M, Weiss L, Dougall WC, Greene MI and Guroff G: Down-regulation of c-neu receptors by nerve growth factor in PC12 cells. J Neurochem 65: 427-433, 1995.

64. Nahta R, Yuan LX, Zhang B, Kobayashi R and Esteva FJ: Insulin-like growth factor-I receptor/human epidermal growth factor receptor 2 heterodimerization contributes to trastuzumab resistance of breast cancer cells. Cancer Res 65: 11118-11128, 2005.

65. Yang CH, Huang CJ, Yang CS, Chu YC, Cheng AL, WhangPeng J and Yang PC: Gefitinib reverses chemotherapy resistance in gefitinib-insensitive multidrug resistant cancer cells expressing ATP-binding cassette family protein. Cancer Res 65: 6943-6949, 2005 . 